\title{
LEAN MÓDSZEREK ALKALMAZÁSA MAGYARORSZÁGON
}

Az utóbbi idóben megszaporodtak a lean alkalmazásokról szóló beszámolók. A cikk a magyarországi vállalatoknál végzett lean projektekkel foglalkozik. A szerzók feltárják a lean projektek okait és a leggyakrabban használt technikákat. Azt találták, hogy a lean projektek leggyakoribb céljai a hatékonyságnövelés, a költség- és veszteségcsökkentés. Az esetek felében az alkalmazandó módszereket tanácsadók javasolták. Az elemzések azt mutatják, hogy a felsố vezetốk erốteljesen részt vettek a folyamatokban (célkitúzés, módszerválasztás, esetenként a megvalósításban is). A vizsgált lean projekteknél a legnépszerúbb módszerek az 5S, PDCA és a Poka-Yoke voltak. Az esetek kétharmadában külsố tanácsadók segítették a munkát. A cikk szakirodalmi részében egy tömör összefoglalás található a különbözó lean megközelítésekról.

\section{Kulcsszavak: lean alkalmazások, lean módszerek, lean projektek, lean tanácsadók}

A tanulmány célja a Magyarországon megvalósított lean projektek vizsgálata. A felpezsdült lean mozgalom keretében különbözô vállalatok kezdenek bele lean módszerek alkalmazásába. Joggal merül fel a kérdés, hogy mi a közös és mi az eltéró ezekben a projektekben, van-e legjobb módszer. Célunk az is, hogy a gyakorlati alkalmazók, kutatók és oktatók számára képet adjunk a többféle bevezetési módra. Ilyen lehetôségek például a külsố és/vagy belsố tanácsadók alkalmazása, az alkalmazott lean módszerek kérdése.

Jelen dolgozatnak tervezzük egy olyan folytatását is, amely nem a lean bevezetések sajátosságaival, hanem azok eredményeivel foglalkozik.

A lean projektek jellemzóinek vizsgálatát nemzetközi szinten is több tényező indokolja. Az egyik a lean menedzsment fokozódó elterjedtsége. Dankbaar (1997) szerint ,a lean termelés lesz a XXI. század szabványos termelési módja”. Ennek megfelelően egyre több a vállalati alkalmazás és az ezekról szóló szakirodalmi beszámoló (Kovács, 2004; Radnor et al., 2006; Hollweg, 2007). Moyano-Fuentes és Sacristán-Díaz (2012) egy átfogó, szakirodalmi alapú áttekintést ad a kezdetektôl indulóan.

A vizsgálat másik indoka, hogy maga a lean koncepció is folyamatos fejlődésben van. Amikor a lean projektek hatását elemezzük, akkor tekintettel kell lenni arra, hogy a lean felfogás nem egységes. Történel- mileg, idóben is változik, az alkalmazók felfogásától is függ.Egyes szerzók például a leant egy fontos költségcsökkentési eszköznek gondolják - ahogyan arra Jenei - Renczes - Losonci (2012) is utal -, míg mások ezt tagadva azt hangsúlyozzák, hogy a lean nem költségcsökkentési eszköz. Karlsson és Åhlstöm (1996) például a leant tágan értelmezik, amelybe különböző vállalati funkcionális területek tartoznak, nem csak a termelés.

Történelmileg két irányultság, fejlődési szakasz különböztethetô meg:

- a TPS alapján a veszteség/pazarláscsökkentés (Ohno, 1988),

- folyamatszemlélet, értékalapú megközelítés (Womack, 1990).

Az elsônél hangsúlyozottan jelennek meg a TPS elemei. Itt a karcsúsítást a felesleges eróforrás-felhasználás (pazarlás) csökkentése, a veszteségek elkerülése jelenti.

A második, ma egyre inkább terjedó felfogás általánosan értelmezi a leant, amelyben - az előzőek megtartása mellett - fokozottabban jelenik meg az értékteremtés szerepe, a folyamatos áramok kialakulása.

Tartalma mellett a lean körülhatárolható a más filozófiákkal történő kapcsolata szerint is, ami szerző́nként szintén változik. 
Történeti okokból adódóan, illetve történeti áttekintésekben a leant leggyakrabban a Toyota termelési rendszerével, a TPS-sel együtt említik. A kettő viszonyának értelmezésében széles a skála. Előfordul, hogy a kettőt azonosnak tekintik, esetenként a lean a TPS összetevője, de maga a TPS is lehet egy lean megvalósítás. Ebben a felfogásban a lean veszteségcsökkentő eszköz.

Hasonló a viszony a TQM-mel, amelynek egyik összetevője a folyamatos tökéletesítés (kaizen), amely

A különbözó filozófiák nagyrészt közös módszereket alkalmaznak (Kovács-Uden, 2010)

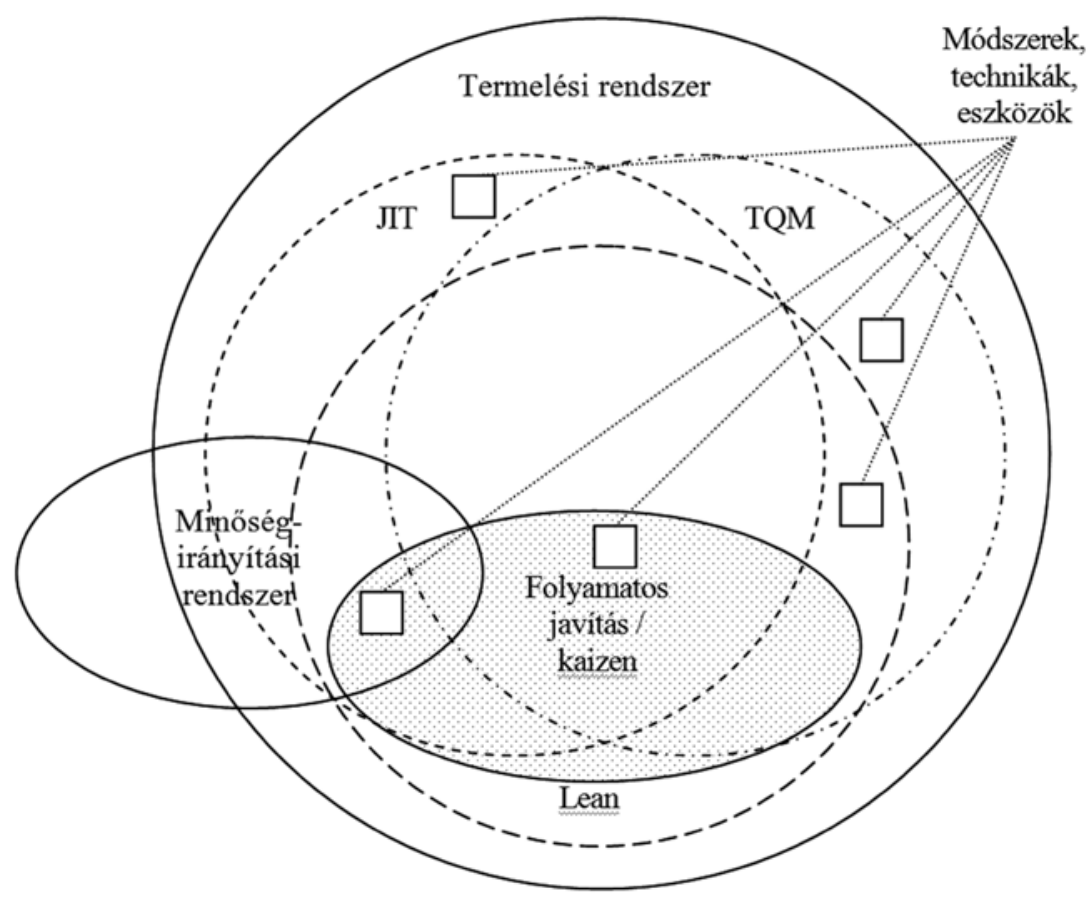

A válság idején nốtt a leant alkalmazó cégek aránya az USA-ban (RSM McGladrey, 2012)

\begin{tabular}{|l|l|l|}
\hline Ipari szegmens & $\mathbf{2 0 0 8}$ & $\mathbf{2 0 0 9}$ \\
\hline Ipari felszerelések gyártása & $61 \%$ & $65 \%$ \\
\hline Étel- és italgyártás & $45 \%$ & $52 \%$ \\
\hline Fémfeldolgozás & $68 \%$ & $68 \%$ \\
\hline Közlekedési eszközök gyártása & $42 \%$ & $70 \%$ \\
\hline Építóanyagok gyártása & $51 \%$ & $55 \%$ \\
\hline Múanyagok gyártása & $65 \%$ & $64 \%$ \\
\hline Elektronikai termékek gyártása & $61 \%$ & $67 \%$ \\
\hline Vegyi anyagok gyártása & $55 \%$ & $59 \%$ \\
\hline Nyomtatás, könykiadás & $55 \%$ & $51 \%$ \\
\hline Orvosi eszközök gyártása & $61 \%$ & $87 \%$ \\
\hline Összesen & $\mathbf{5 6 \%}$ & $\mathbf{6 1 \%}$ \\
\hline
\end{tabular}

több célra irányulhat, ezek közé - a vevői elégedettség mellett - a veszteségek kiküszöbölése is tartozik. A TQM átvezet a minőségügyi gondolatkörbe, hiszen a lean is TQM/folyamatos tökéletesítési/minôségügyi eszközöket használ.

A JIT-felfogás hagyományosan az alacsony készleteket helyezi a középpontba, azonban az alacsony készletekkel történô termelés csak problémamentes környezetben lehetséges, ehhez pedig folyamatos töké1. ábra letesítés kell, ami kaizen/lean/TQM keretben történhet.

Jelen cikk szerzói nem tesznek éles különbséget a lean, TQM, kaizen, TPS, JIT, folyamatos tökéletesítés között. Felfogásuk szerint azonos módszertani alapokra (toolbox) épülnek (1. ábra). Közöttük olyan alapvetô nézôpontbeli különbségek vannak, amelyek akár egy filozófián belül is elófordulhatnak az egyes alkalmazók, szerzók között.

Az alkalmazást tekintve különösen igaz, hogy a bevezetési projekt névválasztása akár változásmenedzsment-eszköz is lehet. Ezt befolyásolhatja a divat, vagy akár a korábbi negatív tapasztalatok. A mai leanhez hasonló tartalmú projekteket az 1990-es években kaizen projekteknek hívták (vagy még korábban racionalizálásnak). ${ }^{1}$

Természetesen nem kell lebecsülni a bekövetkezett fejlődés hatását. Az idóközben megjelent publikációk (Womack - Jones, 2003; Demeter et al., 2011) olyan tényezókre (például vevôi érték, értéknövelés) világítanak rá, amelyek a változó kihívásoknak - például múszaki fejlődés, válság - jobb megfelelést eredményeznek.

Ezt igazolja, hogy az RSM McGladrey 920 vezetôt megkérdező felmérése (RSM McGladrey, 2012) szerint a leant alkalmazó vállalatok aránya a gazdasági válság idején tovább nôtt (1. táblázat).

Amiatt sem célszerú a lean és a többi filozófia közötti erôteljes különbségtétel, mert a megvalósult, múködő rendszerek korántsem olyan 
konzisztensek, mint amilyennek a szakirodalmak többsége láttatja. Magának a Toyota termelési rendszernek az értelmezése sem egységes. Liker és Rother (2011) például a gyakori félreértésekre ad példát. Takeuchi és szerzótársai (2008) rámutatnak a Toyota termelési rendszerében meglévő (látszólagos) ellentmondásokra, amelyeket éppen a fejlődés és a reagálóképesség egyik hajtóerejének tartanak. Koenig (2013) szerint is sok a közös elem a különbözô folyamatmenedzsment-technikák, mint a lean, six sigma és a BPM között. „Közösek a minőségi és termelékenységi céljaik. Egyaránt a folyamatoptimalizálásra és statisztikai elemző módszerekre összpontosítanak a hatékonyság elérése érdekében."

A lean alkalmazások szektoriális fejlődése jól nyomon követhető az Aberdeen Group egyéb tanulmányain keresztül (http://www.aberdeen.com). Több olyan tanulmányuk van, amely a lean és egyéb folyamatfejlesztési módszerek alkalmazásával foglalkozik.

\section{Szakirodalmi elốzmények}

Az utóbbi idóben megszaporodtak a leannel kapcsolatos kutatásokról szóló hazai és nemzetközi beszámolók (Shah - Ward, 2007; Gelei et al., 2011; Losonczi, 2011; Kelemen, 2009).

Korábbi - például versenyképességi - vizsgálatok egyes részei is értelmezhetôk mai felfogásban leanre irányulónak. Demeter és szerzótársai a ,,Versenyben a világgal" kutatási program keretében vizsgálták a vállalatok által bevezetett változtatásokat és azok hatásait (Demeter et al., 2011). Egy másik tanulmányukban (Gelei et al., 2011) az alkalmazási körülmények között azt vizsgálták, hogy van-e kapcsolat a vállalati lean alkalmazás és a vezetôi stílusok között. Azt találták, hogy a sikeres lean bevezetés igényli a határozott vezetést. A szerzők szakirodalmi összefoglalásaikkal és esettanulmányaikkal jelentősen hozzájárultak a hazai lean szakirodalom gazdagodásához. A lean iránti fokozott érdeklődést mutatja a témával foglalkozó PhD-kutatások növekvố száma.

Liker és Rother (2011) többéves kutatás alapján azonosítják a lean projektek kudarcának okait. Ehhez kapcsolódóan tanácsadók is megosztják tapasztalataikat.

\section{Saját kutatás}

Bármelyik lean megközelítést is tekintjük, közös bennük, hogy többnyire jól körülhatárolható készletból származó különbözố módszereket alkalmaznak valamilyen rendszer múködésének tökéletesítése érdekében.

A hazai, és talán a nemzetközi alkalmazásokra is igaz, hogy többnyire projektek keretében vezetik be óket, és a projektek lefutása után az eredmények fenntartása, továbbfejlesztése egyáltalán nem megoldott feladat.

Kutatásunk során néhány kiválasztott példán keresztül azt vizsgáltuk, hogy hazai környezetben hogyan valósultak meg lean projektek.

\section{A kutatás bemutatása}

A kutatás célja a hazai lean projektek tartalmának, megvalósításának vizsgálata. Bár tartalmilag a lean és a többi (kaizen, TQM) erőfeszítések között esetenként kicsi lehet a különbség, a felmérésben kizárólag olyan vállalatok szerepeltek, amelyeknél ,lean” megnevezéssel történt a módszerek alkalmazása.

A fóbb kutatási kérdések:

- Mi volt a lean projekt célja?

- Milyen szervezeti, szervezési keretek között hajtották végre a lean projektet?

- Milyen módszereket alkalmaztak?

- Milyen az egyes módszerek ismertsége?

- Milyen az alkalmazási körülmények, például a vezetốk érintettsége, tanácsadók igénybevétele?

Jelen tanulmányban 65 vállalattól származó adatok feldolgozásának eredményéról számolunk be. A vizsgálatban résztvevoóket a következő körből választottuk ki: lean események (lean estek) résztvevôi, lean tanácsadók és website üzemeltetốk adatbázisa, általunk ismert lean alkalmazók. A lekérdezés a limesurvey rendszer felhasználásával történt. Bár a kérdőív anonim volt, csak általunk kapott, személyre szóló token birtokában lehetett kitölteni.

A mintában szereplő vállalatok túlnyomó része, 51 a feldolgozóiparból származott.

Egy-egy vállalat került még be a bányászati szektorból, az építôiparból, a szállítás és raktározásból és az oktatásból, kettő a villamosenergia-, gáz- és vízellátásból, a kereskedelemból, a pénzügyi közvetítésból, az ingatlanügyletekból és az informatikából.

A szakmai profilt tekintve a feldolgozóiparon belül, annak 10\%-a feletti részaránnyal szerepel a jármúgyártás, a fémalapanyag, fémfeldolgozási termék gyártása és a villamos gép, múszer gyártása. A válaszadók saját ágazatukat úgy jellemezték, mint amelyre az idóbeli ingadozás jellemző.

\section{Az eredmények}

Az elterjedt közfelfogás szerint a korszerú módszerek alkalmazásában a külföldi tulajdonú vállalatok járnak élen. A kapott eredmények ezt megerősítették. A vizsgált gazdasági szervezetek túlnyomó részében külföldi tulajdonban álltak, 16,9\% a többségében hazai tulajdonban lévố szervezetek aránya (2. táblázat). 
Elsôsorban a nagy, külföldi tókével rendelkezô vállalatok indítanak lean bevezetési projekteket

\begin{tabular}{|c|c|c|c|c|c|c|c|}
\hline \multirow[t]{2}{*}{ Az alkalmazottak száma } & \multicolumn{6}{|c|}{$\begin{array}{c}\text { A külföldi tóke aránya } \\
\text { (A válaszok gyakorisága) }\end{array}$} & \multirow[t]{2}{*}{ Összesen } \\
\hline & $0 \%$ & $1 \%-20 \%$ & $21 \%-40 \%$ & $41 \%-60 \%$ & $61 \%-70 \%$ & $81 \%-100 \%$ & \\
\hline $1-10$ & 2 & 0 & 0 & 0 & 0 & 0 & 2 \\
\hline $11-50$ & 0 & 0 & 0 & 0 & 0 & 1 & 1 \\
\hline $51-25 \mathrm{e}$ & 1 & 0 & 1 & 0 & 0 & 8 & 10 \\
\hline $251-1000$ & 4 & 1 & 1 & 2 & 1 & 25 & 34 \\
\hline 1000 felett & 1 & 0 & 0 & 0 & 0 & 17 & 18 \\
\hline Összesen & 8 & 1 & 2 & 2 & 1 & 51 & \\
\hline
\end{tabular}

A kiszervezés mértéke

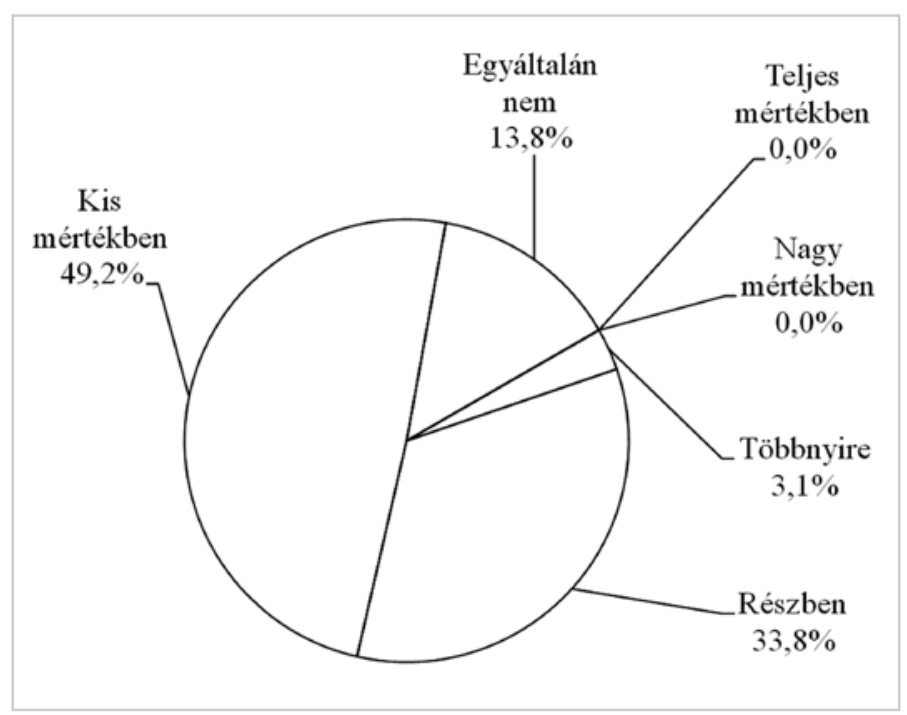

A kibocsátott termék vagy szolgáltatás mérése

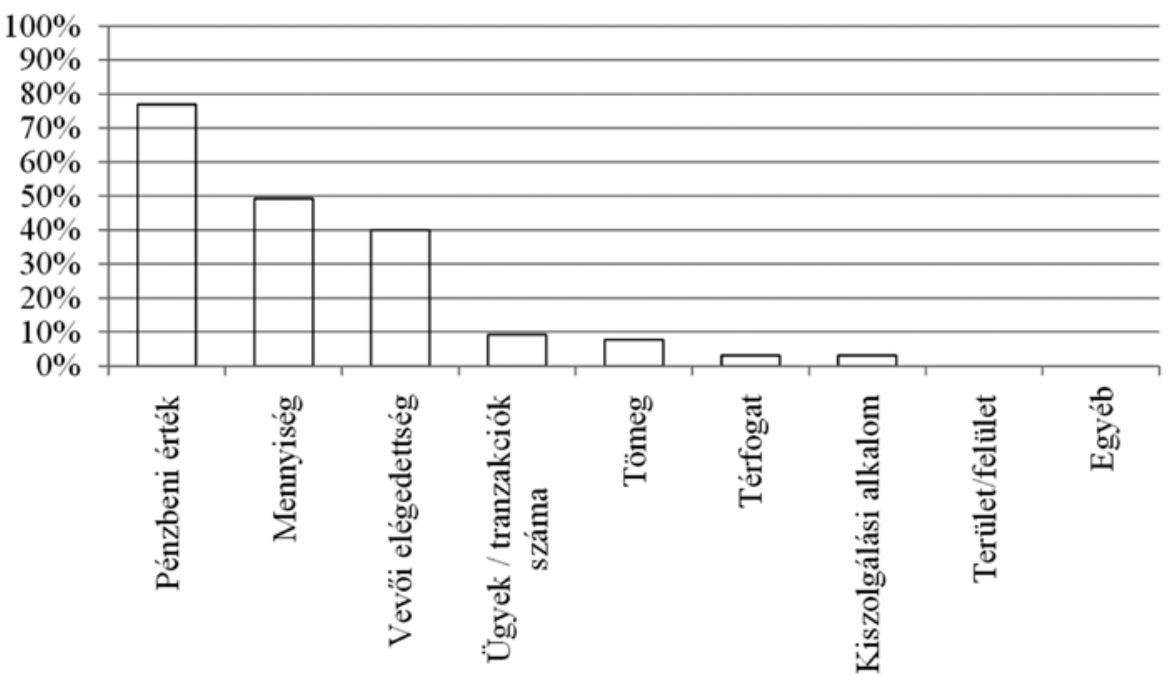

A mintába került - leant alkalmazó - vállalatok jellemzően nagyobb méretúek.

$\mathrm{Az}$ árbevételt tekintve 67,2\%-uk egymilliárd $\mathrm{Ft}$ feletti árbevétellel rendelkezik, 80\% 251 fő feletti létszámot foglalkoztat.

A lean erófeszítések a mintában jelentős részben $(58,5 \%)$ a fő folyamatra irányultak. Az eredmények megerôsítik RSM McGladrey felmérésból levonható következtetését, ami szerint a lean segít a válság leküzdésében. A válaszadók 89\%-ának volt ez a véleménye. Néhány kis, a leant önmagukon alkalmazó cég is szerepelt a mintában.

Érdekes kérdés a lean és a kiszervezések viszonya. A lean karcsúsítási felfogása ugyanis kiszervezést erôsítő hatású. A felmérés ezt a hatást nem erôsítette meg (2. ábra).

Kölcsönmunkaerốt a válaszadók 52,4\%-a alkalmazott, kis részük $(13,8 \%)$ pedig egyáltalán nem élt

3. ábra ezzel a rugalmasságot biztosító eszközzel. A folyamatok kimenetének mérési módja utal a célokkal kapcsolatos beállítódásra (3. ábra).

A kibocsátott termék vagy szolgáltatás mérésekor a gazdasági szereplók többnyire a pénzbeli értéket választották (76,9\%), kisebb részben követték a mennyiségi adatokat és a vevői elégedettséget és az ügyletek/tranzakciók számát.

A folyamatok összehangoltsága utal az általános állapotokra (4. ábra).

A válaszadók 13,8\%-a szerint a szervezeten belüli folyamatok teljesen összehangol- 


\section{A folyamatok összehangoltsága}

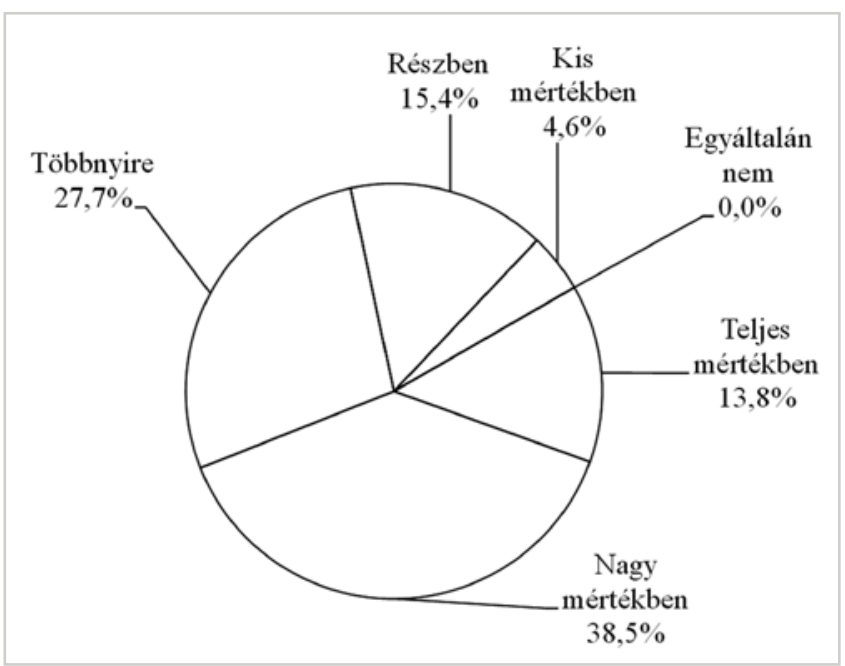

tak, 66,2\%-uk szerint történtek már optimalizálások, és csak 4,6\% válaszolta azt, hogy a folyamatok összehangoltsága kismértékú.

A 3. táblázat a célok és a mutatószámok gyakorisága szerinti sorrendeket tartalmazza. A megkérdezett vállalatok különböző mérőszámokat alkalmaztak a célok elérésének mérésében. Leggyakrabban az átfutási idővel, a minőséggel és a hatékonysággal kapcsolatos mutatószámot alkalmazták. Érdekes, hogy a rendelkezésre állást csak kevesen használják mint mutatószámot.

A lean eszközök alkalmazásainak céljai között elsô helyen szerepel a hatékonyságnövelés (93,8\%), amit a költségek csökkentése és a veszteségek megszüntetése követ 67,7 és 66,2\%-kal (5. ábra). A költségmegtakarí- tás előkelő helye egybeesik Jenei - Renczes - Losonci (2012) véleményével. Érdekes módon a válaszadók felénél volt fontos a jobb minôségú végtermék vagy az ügyfél-elégedettség növelése. Ez megerôsíti a lean és a TQM filozófia rokonságát. Leszúrhetô az is, hogy lean eszközöket - bár más válaszok szerint alkalmas lenne rá - nem a krízishelyzetek kezelésére és a jobb pénzügyi ellenőrzés megvalósítására alkalmaznak a szereplốk.

Megfigyelhető, hogy a célok és mérôszámok nagyjából azonos területeket fednek le, a gyakoriságuk azonban eltérô. A célokat össze tudjuk hasonlítani a szakirodalomban szereplőkkel. A 3. táblázat Atkinson (2004) célrendszerét is tartalmazza. A célelérés mérōszáma és a cél független kérdések voltak.

Nyilvánvaló, hogy a célok között van kapcsolat. Itt elsősorban az az érdekes, hogy a lean projekt kezdeményezói mit tekintettek olyan hívó szónak, ami támogatást generálhat az érintetteknél, elsôsorban a menedzsmentnél és a dolgozóknál.

A szakirodalomban többféle statisztika található a különböző projektek sikerességi arányáról. Általános felfogás szerint például az informatikai projektek kevesebb mint fele tekinthető teljesen sikeresnek. (Több felmérés tapasztalata található a thttp://calleam.com/ WTPF/?page_id=1445 webhelyen.) Ezért - fokozatokat alkalmazva - rákérdeztünk a sikeresség értékelésére. Az eredményeknél (5. ábra) figyelembe kell venni, hogy a válaszadók érintettek voltak a projektek megvalósításában. Vizsgálataink megerôsítik Staats és Upton (2007) eredményeit, ami szerint a lean projektek általában - de nem mindig - jobban teljesítenek, mint az egyéb projektek.

3. táblázat

Célok és mutatószámok lean projektekben

\begin{tabular}{|c|l|l|l|}
\hline Sorrend & \multicolumn{1}{|c|}{ Célelérés mérószáma } & \multicolumn{1}{|c|}{ Cél } & \multicolumn{1}{c|}{ Atkinson (2004) szerinti cél } \\
\hline 1. & Hatékonysági mutatók & Hatékonyságnövelés & Költségcsökkentés \\
\hline 2. & Átfutási idó & Költségcsökkentés & Sajátos fenyegetések elkerülése \\
\hline 3. & Minóség & Veszteségek megszüntetése & A termék vagy elosztás minősége \\
\hline 4. & Költségmegtakarítás & Átfutási idő csökkentése & Azátfutási (ciklus) idócsökkentése \\
\hline 5. & Taktidó & Készletcsökkentés & Új termék vagy szolgáltatás indítása \\
\hline 6. & Készletérték & Jobb minóségú végtermék & A legjobb érték kifejlesztése \\
\hline 7. & Létszám & Ügyfélelégedettség növelése & \\
\hline 8. & Munkaóra & Standardizálás bevezetése & \\
\hline 9. & Készletforgás & Magasabb jövedelmezóség elérése & \\
\hline 10. & Rendelkezésre állás & Magasabb szolgáltatási szintelérése & \\
\hline 11. & Felületnagyság & Szinkronizált folyamatok bevezetése & \\
\hline 12. & & Krízishelyzet kezelése & \\
\hline 13. & & Jobb pénzügyi ellenórzés & \\
\hline
\end{tabular}




\section{A feltárt potenciálok megvalósítása}

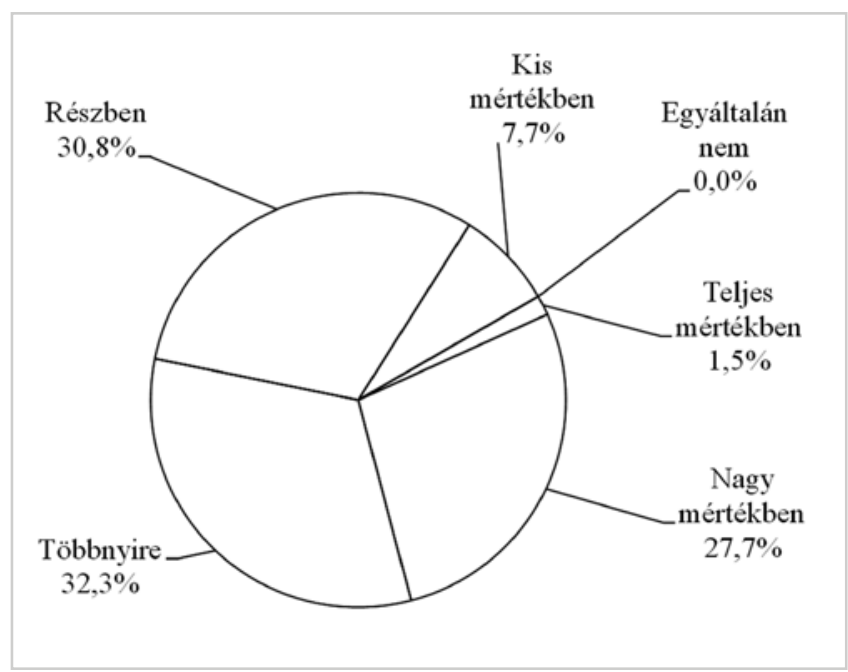

A kapott eredményt nehéz egy mondatban értelmezni. (Ebben az esetben az igen-nem válasz egyértelmúbb lenne, de az árnyaltabb kép érdekében általában fokozatokat alkalmaztunk.) A válaszadók 29,2\%-ánál sikerült a feltárt potenciálokat teljesen vagy nagymértékben megvalósítani, míg csak 7,7\%-uk mondta, hogy szinte alig voltak kivitelezhetốk a javaslatok. Az összképet pozitívnak értékeljük.

A bevezetési projektek életciklusának talán legfontosabb szakasza a fenntartás. A projektek indítását követô kezdeti lelkesedés idővel csökkenhet. A vállalati és egyéni célok változhatnak, új feladatok adódnak, a negatív reakciók, kudarcok csökkentik a lelkesedést és érvényesülhet az értékrend, a kultúra visszahúzó hatása is. A 6. ábrán látható a megkérdezettek véleménye az eredmények fenntartásával kapcsolatban.

\section{Az eredmények hosszú távú fenntartása}

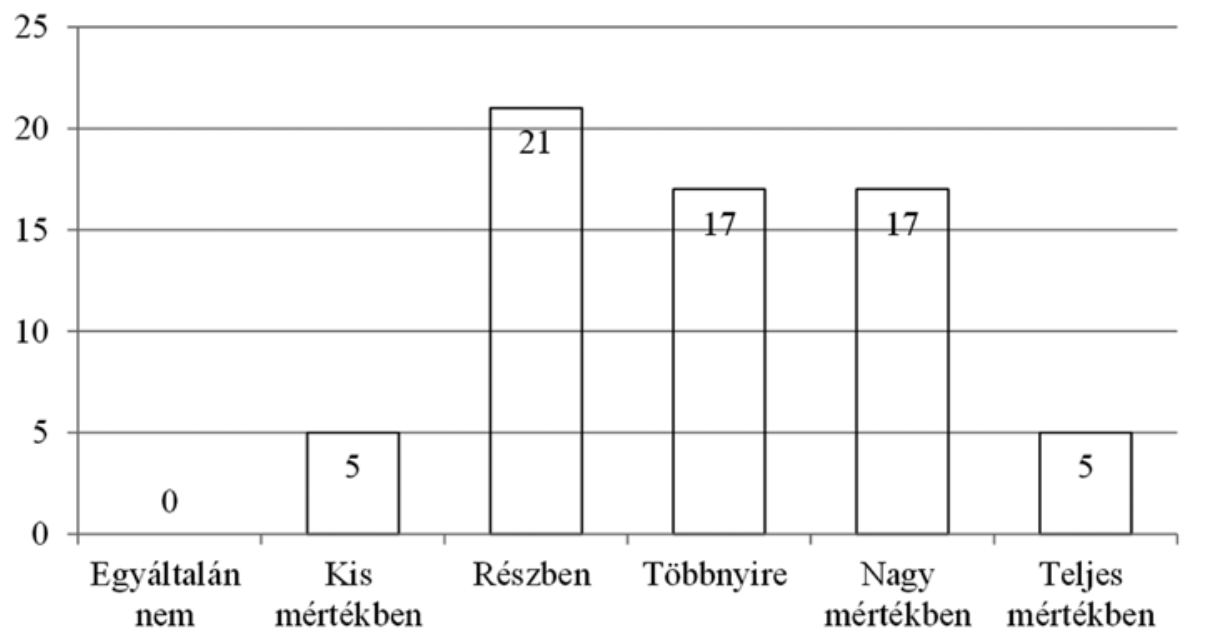

Az elért eredmények hosszú távú fenntartása mindössze 7,7\%-uknál sikerült teljes mértékben, 52,3\%-nál már voltak visszalépések, és 7,7\%-uk szerint az eredményeket csak kismértékben sikerült megvalósítani. Itt is figyelembe kell venni, hogy ez az eredmény önértékelés alapján adódott.

A lean projektek változást jelentenek a szervezet életében. Mint minden változásnál, itt is felléphetnek ellenzô reakciók. A 7. ábra alapján megállapítható, hogy a válaszadók majdnem negyedénél $(23,1 \%)$ tapasztaltak erôs munkatársi ellenállást a lean eszközök alkalmazása kapcsán, 69,3\%-uknál kismértékú, 7,7\%-uknál pedig semmilyen munkatársi ellenállás nem volt tapasztalható.

7. ábra

\section{A munkatársi ellenállás}

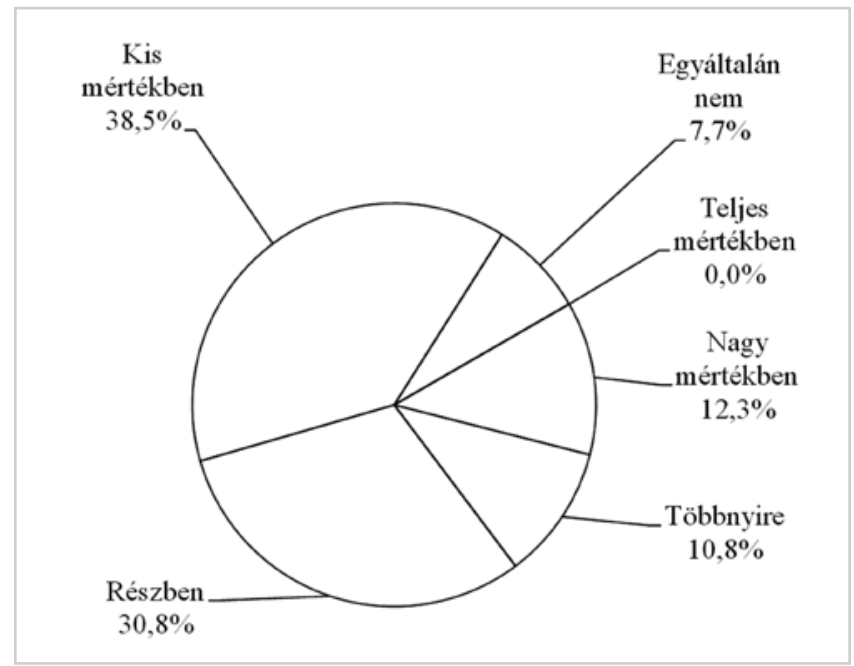

A munkatársi ellenállás mellett a lean eszközök alkalmazása során egyéb akadályozó tényezók is fel-

6. ábra léphetnek. Az alkalmazások során felmerült problémák leküzdésének sikerességét a válaszadók a 8 . ábra szerint ítélték meg.

A válaszadók kevéssel több mint egyharmadánál $(35,4 \%)$ sikerült a lean eszközök alkalmazása során felmerült problémákat teljesen vagy nagymértékben megoldani, 20\%-uknál már csak részben, míg 6,2\%-uknál csak kismértékben volt ez lehetséges.

A veszélyérzettel kapcsolatos válaszok megoszlását a 9 . ábra mutatja. 


\section{A felmerülő problémák leküzdése}

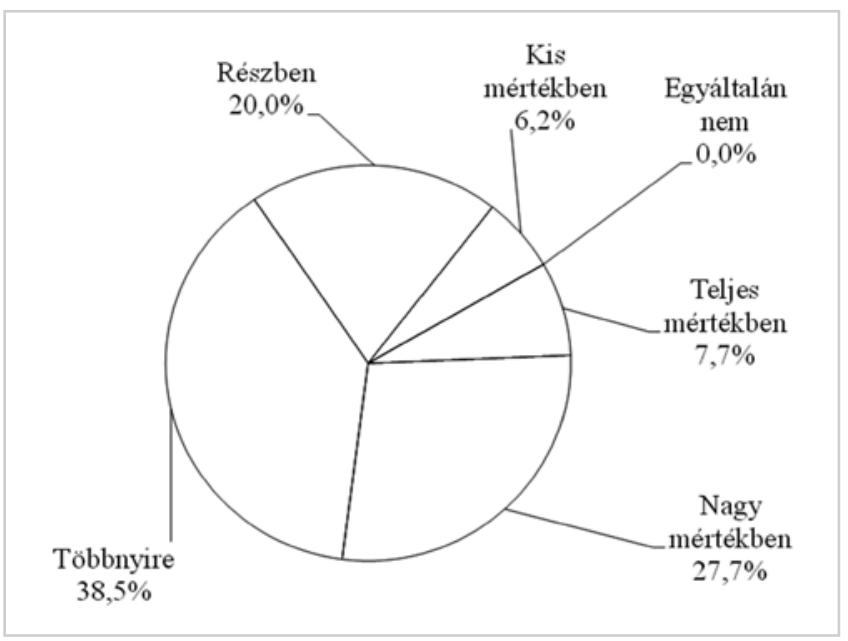

Veszély az intézkedések bevezetésében

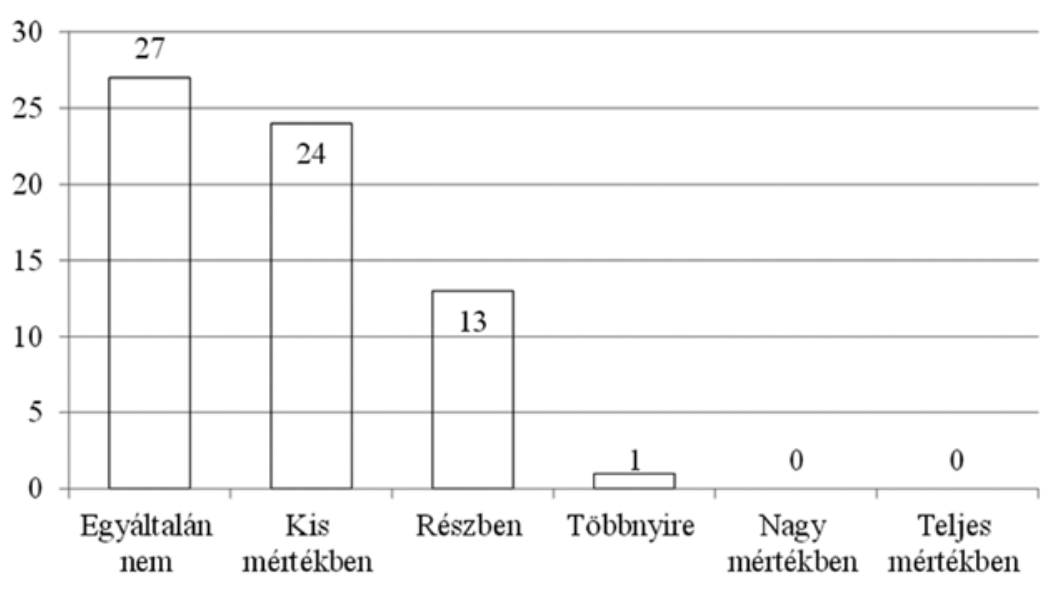

Honnan értesültek a lean eszközökról?

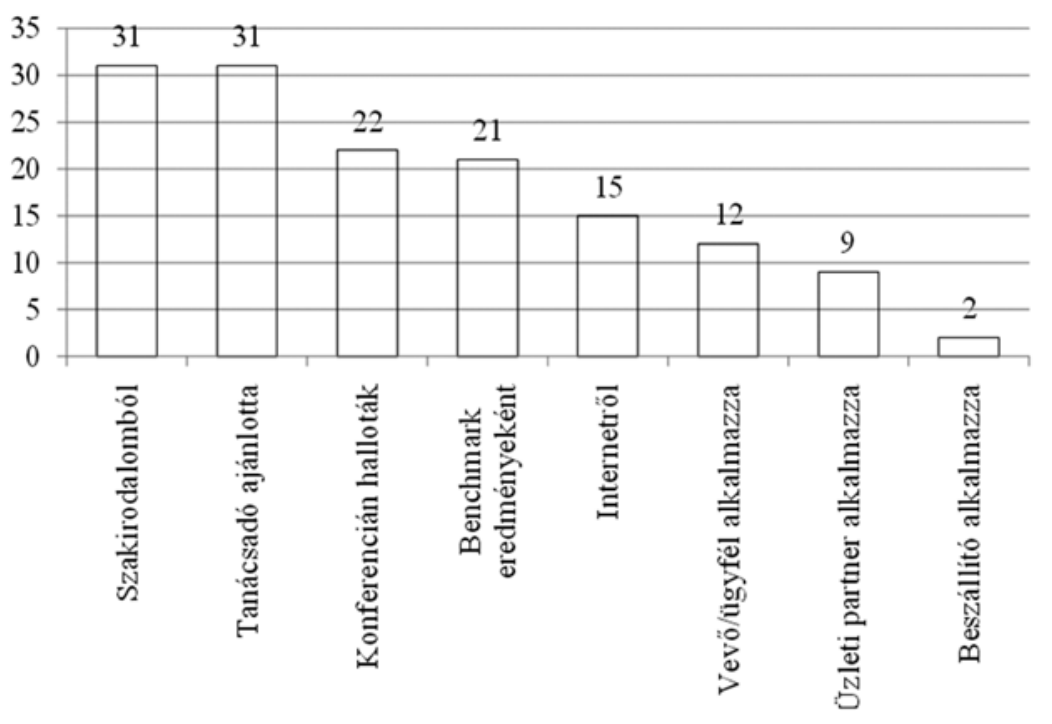

Érdekes módon mindössze a válaszadók 21,5\%-a érzett kisebb veszélyt az intézkedések bevezetése során, míg 41,5\% egyáltalán nem tapasztalt ilyet.

A kiválasztott lean eszközöket többnyire tanácsadók ajánlották vagy a válaszadók maguk néztek utána szakirodalomban $(47,7-47,7 \%)$, és egyharmaduk $(33,8 \%)$ konferencián hallott róla elôször (10. ábra). A válaszadók több forrást is megjelölhettek.

A válaszadók felénél azért azt vagy azokat a lean eszközöket alkalmazták, mert gyors célelérést biztosít $(49,2 \%)$, esetleg az anyavállalat is alkalmazza $(40,0 \%)$. Maga a könnyú érthetôség mindössze a válaszadók 30,8\%-ánál játszott szerepet (4. táblázat).

Az eredmények értékelésénél figyelembe kell venni, hogy a kérdés megválaszolásakor adott lehetôségek közül kellett választani. Az alacsony "egyéb” részarány

9. ábra

4. táblázat

Okok, amiért

az alkalmazott lean eszközöket választották

\begin{tabular}{|c|c|c|}
\hline 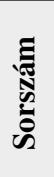 & A módszerválasztás oka & 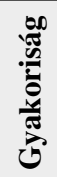 \\
\hline 1. & Gyors célelérést biztosít & 32 \\
\hline 2. & Könnyen alkalmazható & 26 \\
\hline 3. & $\begin{array}{c}\text { Az anyavállalat is ezt } \\
\text { használja }\end{array}$ & 25 \\
\hline 4. & Vezetối döntés révén & 25 \\
\hline 5. & Könnyen érthető & 20 \\
\hline
\end{tabular}

azonban azt mutatja, hogy az adott lehetôségek lefedték a valós szempontokat. A válaszadók ez esetben is több okot jelölhettek meg. Érdekes kérdés lehet a vezetôi és végrehajtói szerep egyidejú megjelenése az egyes érintettek tevékenységében, hiszen a lean filozófia szerint a tökéletesítés mindenki feladata. A válaszadók csaknem felénél $(49,2 \%)$ a döntési hatáskörrel rendelkezố személyek részt vettek az eszközök alkalmazásában, és mindössze kis részük az, akik egyáltalán nem, vagy kismértékben $(3,1 \%$ és 4,6\%).

A lean megvalósítással kapcsolatos valós vezetôii elkötelezettség mérhetô azzal, hogy a vezetók mennyire követik nyomon a bevezetési projekt alakulását. A döntési hatáskörrel rendelkezô személyek általában követték is a megvalósulást, azonban 
Lean képzések a vezetốk számára

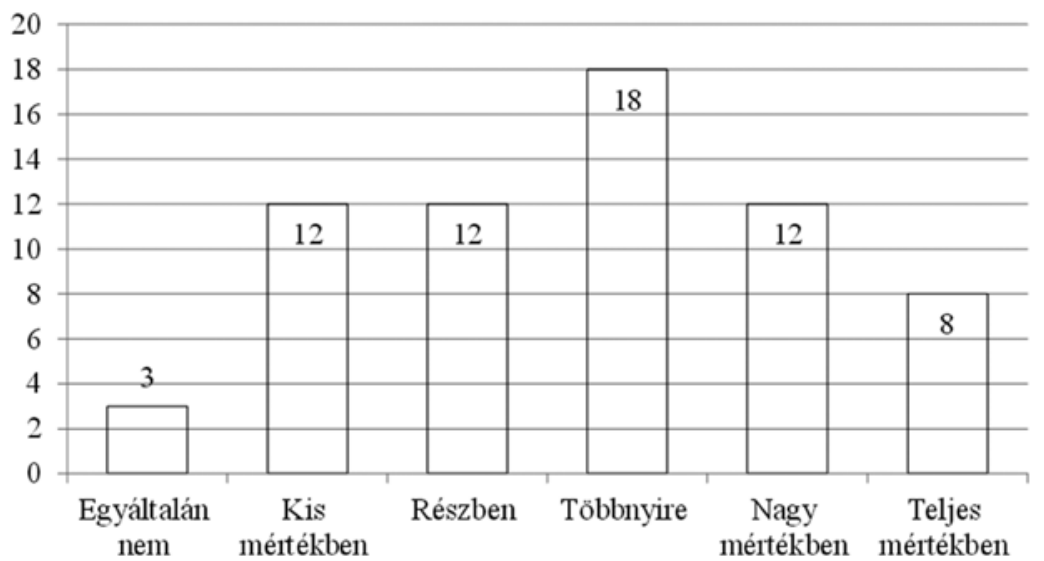

A vezetók felismerték a folyamatos javítás jelentőségét

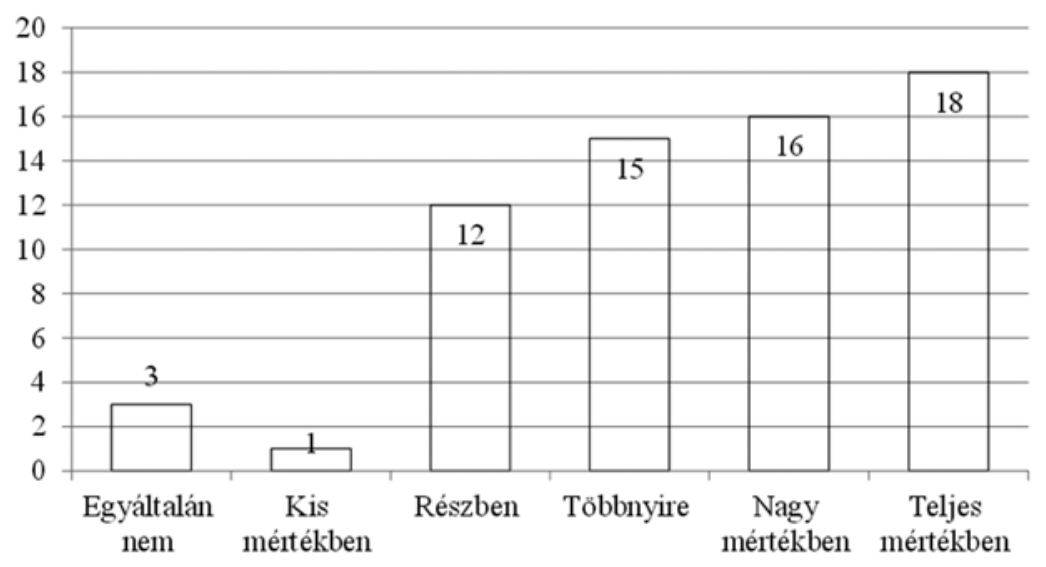

A vezetók tudatosan alkalmazzák a lean eszközöket

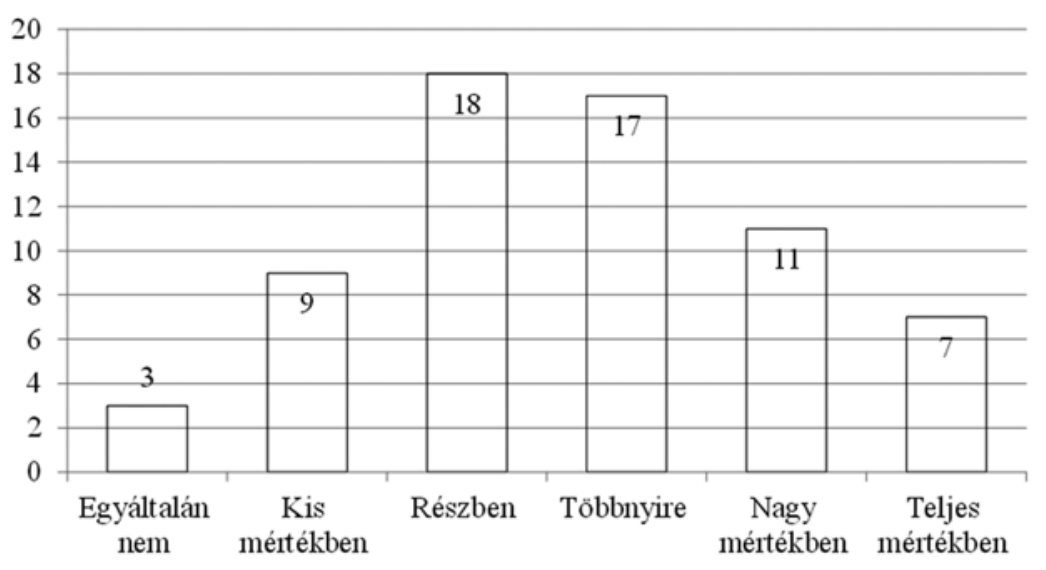

részvételük észrevehetően alacsonyabb arányú. Itt magas volt a nem válaszolók aránya. A döntési hatáskörrel rendelkezô személyek nagyobb mértékben vettek részt a bevezetésben, mint az eredmények követésében. Ez tanulságos a fenntarthatóság szempontjából. Jó lenne, ha a kevésbé látványos fenntartási szakasz több vezetôi támogatást kapna.

A válaszadók majdnem egyharmadánál fektettek nagy hangsúlyt a vezetők lean képzésére (30,8\%), míg további 46,2\%-uknál tartották ezt fontosnak, míg 23,1\%-uk nem igényelte ezt az elemet (11. ábra).

A lean filozófia egyik lényeges eleme a folyamatos tökéletesítés. A vezetôktôl elvárható, hogy ennek fontosságát felismerjék (12. ábra).

A megkérdezettek felénél (52,3\%) a vezetôk felismerték a folyamatos javítás jelentôségét, míg csak 6,2\% válaszolta azt, hogy egyáltalán nem. Nem elég azonban csak felismerni az eszközöket. Azok alkalmazása a közvetlen hasznuk mellett lehetőséget ad a vezetôi példamutatásra (13. ábra).

A válaszadók $27,7 \%$-a szerint a vezetők tudatosan alkalmazzák a lean eszközöket, míg 18,5\%-uknál ez még nem jellemző.

Az alkalmazható lean eszközök köre széles. Gyakran 5S-sel kezdik a projekteket. Az eszközök alkalmazási elófordulására adott válaszokból a 14. ábrán (következó oldal) látható kép rajzolódik ki.

Nem mindegyik módszer tekinthető szúkebb értelemben véve lean módszernek (nem is mindegyik módszer), azonban a kapott válaszok utalnak a hihetôségre is, hiszen például az anyaggazdálkodással, automatizálással nagy valószínúséggel az is találkozott, aki leannel soha nem foglalkozott. A listában konkrét módszerek és átfogó filozófiák egyaránt szerepelnek. Vegyük észre, hogy a TQM a középmezônyben helyezkedik el.

A 65 válaszadóból öt olyan volt, aki sem külsô, sem belsô tanácsadót nem alkalmaz. A megkérdezettek 26,2\%-ánál nem alkalmaznak külsô tanácsadókat, 12,5\%-uk nagymértékben, míg 7,7\%-uk szinte teljes mértékben külső szakemberekre bízza a lean eszközök alkalmazását a szervezeten belül (15. ábra). 


\section{Az egyes módszerek alkalmazása} a válaszadók körében

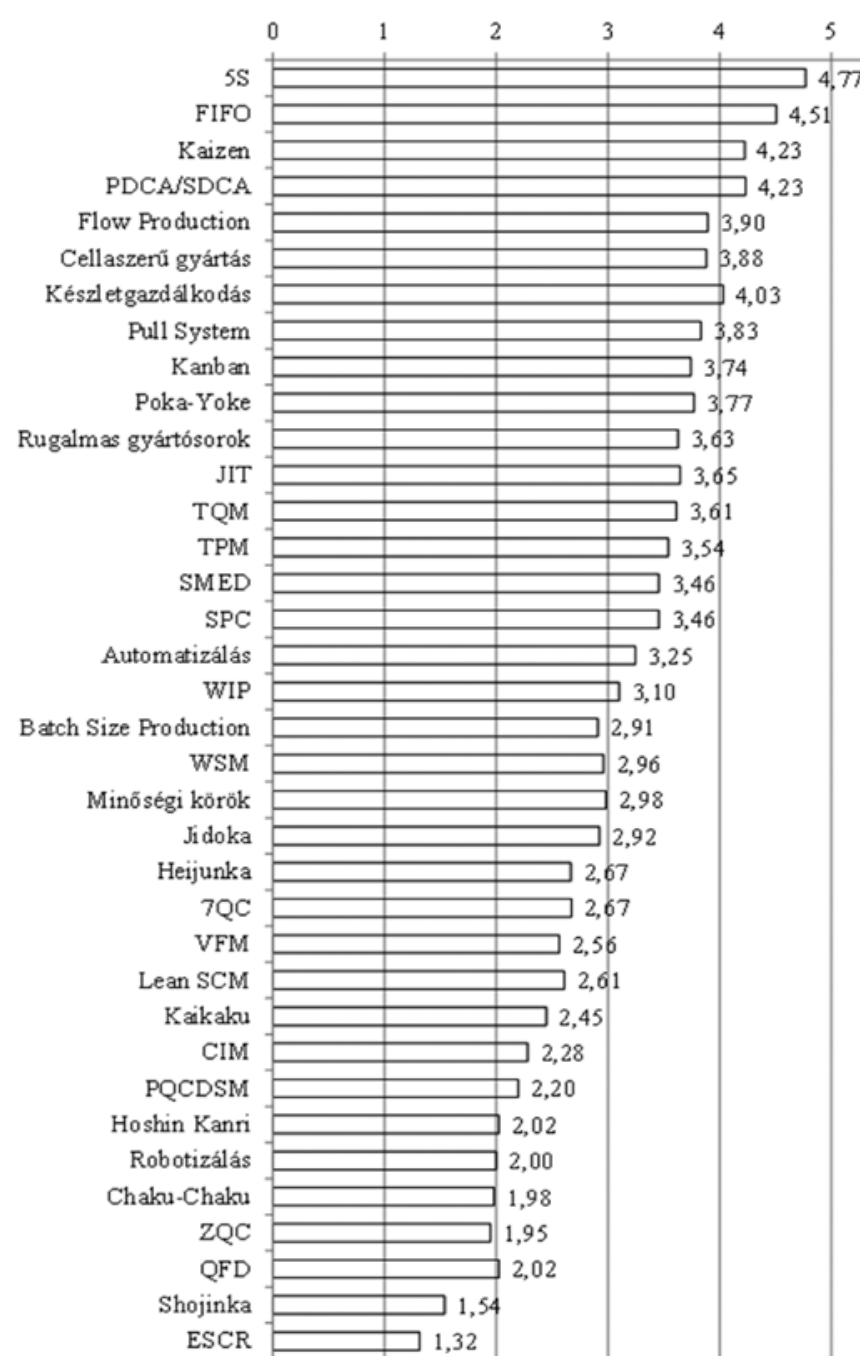

Érdekes módon, akik alkalmaznak külső tanácsadókat, azok nagy részben elégedettek az elvégzett munkával. A megkérdezettek mindössze 16,9\%-a egyáltalán nem alkalmazott belső szakembereket tanácsadásra, míg 38,5\%a nagy vagy teljes mértékben. A tanácsadókkal való elégedettséget a 16. ábra mutatja. Belső tanácsadók alkalmazása kapcsán közel ugyanaz az eredmény, mint külső tanácsadók kapcsán: a megkérdezettek többnyire elégedettek az elvégzett munkával. Érdekes, hogy a külső tanácsadók átlagos értékelése $(4,25)$ kicsit jobb, mint a belsóké $(4,17)$. A mérés 1-6 skálán történt egész értékekkel.

\section{Összefoglalás}

A lean bármelyik vonatkozását - filozófia, módszerek, mozgalom - tekintve megállapítható, hogy a számos hazai alkalmazás lehetőséget ad, és egyúttal igényli, hogy azok megvalósulását áttekintsük. Meg-
14. ábra állapítható, hogy a lean hazai kezdeményezésében és megvalósításában erôteljes a felsô vezetôk és jelentős a külsố tanácsadók szerepe. A lean elsődleges alkalmazási terepét a közepes és nagy iparvállalatok jelentik, közöttük is elsốsorban a külföldi tulajdonú cégek.

A leant alkalmazó vállalatokra nem jellemző az erôs kiszervezés. Úgy tûnik, bár ez csak hipotézis, hogy erôs a kötôdés a saját fő folyamatokhoz. A leant alkalmazó vállalatoknál van egyfajta ,alaprend”, amennyiben ezt a folyamatok összehangoltságával mérjük. A célok és a mutatószámok alapvetôen konzisztens rendszert alkotnak. Azonos szúkebb körból jönnek, továbbá átfednek a nemzetközi szinten tapasztaltakkal. A projektek során jellemzóen közepes vagy gyenge munkatársi ellenállást tapasztaltak, veszélyérzet kevéssé alakult ki. Az, általában felsô vezetốk által, a gyorsaság és könnyú alkalmazhatóság alapján kiválasztott módszerek közül az $5 \mathrm{~S}$ a leggyakrabban alkalmazott. Ennek egyik oka lehet, hogy a projekteket általában 5S-sel kezdik, és ha ott el is akadnak, az már megvan. Annak ellenére, hogy az alkalmazók elégedettek a külsố és belső tanácsadók munkájával, az eredmények fenntarthatósága vegyes képet mutat.

Összességükben a lean projektek hazánkban is sikeresebben az egyéb projekteknél.

A továbbiakban a lean projektek hatását fogjuk vizsgálni. Elemzésünket a lean alkalmazási terület mellett kiterjesztjük olyan vállalati tevékenységekre is, amelyek eredetileg nem voltak a lean projekt célterületei, de a kapcsolatok miatt a hatásuk elvileg érzékelhetô.

\section{Lábjegyzet}

${ }^{1}$ Az 1920-as években kormányzati körökben bevezetett racionalizálási programok sok hasonlóságot mutatnak a mai „karcsú kormányzás" (leangovernance) törekvésekkel.

\section{Felhasznált irodalom}

Atkinson, P. (2004): Creating and Implementing Lean Strategies. Management Services, February: p. 18-21.

Bowen, H.K. (1996): Decoding the DNA of the Toyota Production System. Harvard Business Review, Sept.Oct.: p. 96.

Dankbaar, B. (199): Lean production: denial, confirmation or extension of sociotechnical systems design? Human Relations, 50 (3): p. 653-670.

Demeter K. - Jenei I. - Losonci D. (2011): A lean menedzsment és a versenyképesség kapcsolata. Budapest: Versenyképesség Kutató Központ 


\section{Tanácsadók alkalmazása}

$\square$ Alkalmaztak külső tanácsadókat a gazdálkodó szervezetnél a leaneszközök bevezetésére?

■ Alkalmaznak belső tanácsadókat a gazdálkodó szervezetnél a leaneszközök bevezetésére?

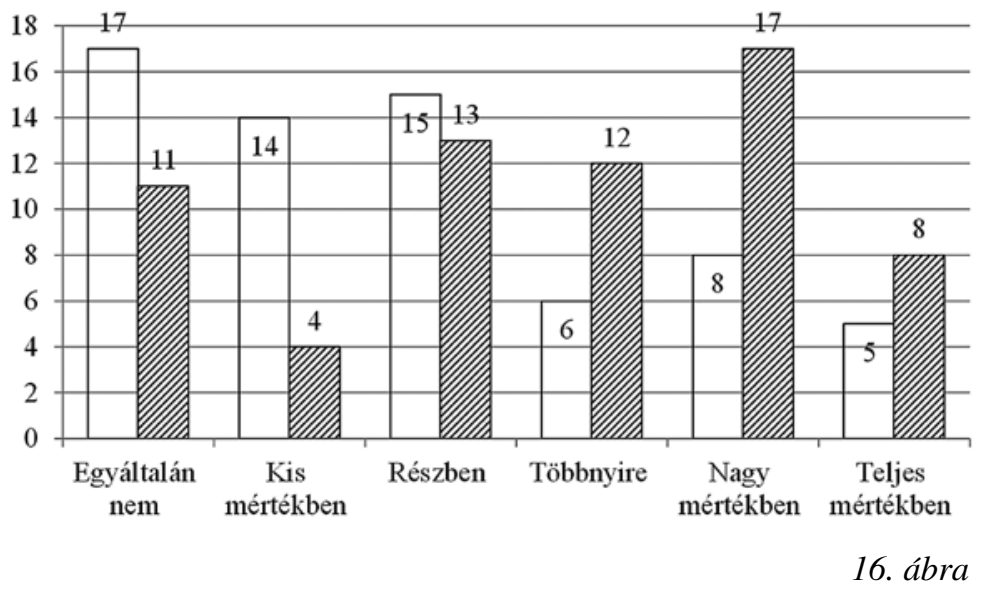

A külsố és belsố tanácsadókkal elégedettek voltak az alkalmazók

口Elégedettek voltak a külső tanácsadók teljesítményével?

$\square$ Elégedettek a belső tanácsadók teljesítményével?

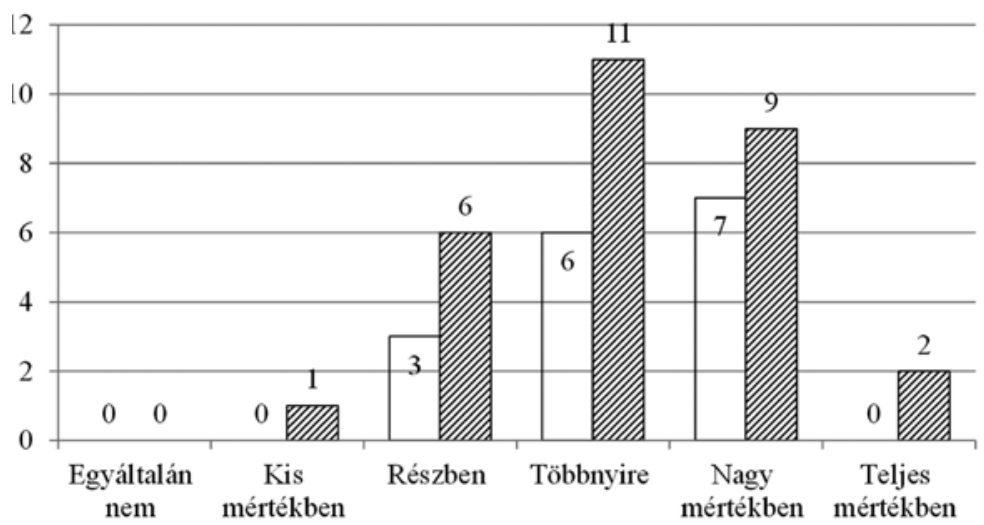

Kovács Z. (2004): A korszerú termelési rendszerek sajátosságai. Harvard Business manager, augusztus: p. 62-69.

Kovács Z. (2008): Termelésmenedzsment. Veszprém: Veszprémi Egyetemi Kiadó

Kovács, Z. - Uden, L. (2010): Overlappings of Co-Creation Supportive Factors in Service Sector Supply Chains. Co-creation Conference. Veszprém,17-18 September 2010. in: Clarke, A. (ed.) (2011): Exploring Co-creation. London, Pearson: p. 85-89.

Liker, J. - Rother, M. (2011): Why Lean Programs Fail, http://www.lean.org/admin/km/ documents/A4FF 50A9-028A-49FD-BB1F-CB 93D52E1878-Liker-Rother\%20Article\% 20v3_5_CM.pdf, Letöltve: 2013. március 4.

Losonczi D. (2011): Emberi eróforrás menedzsment gyakorlatok a lean termelési rendszerben - a stratégiai célok hatása használatukra és múködési teljesítményre gyakorolt hatásukra. Projektzáró tanulmány. Budapest: BCE Vállalatgazdaságtan Intézet Versenyképesség Kutató Központ

Moyano-Fuentes, J.- Sacristán-Díaz, M. (2012): Learning on lean: a review of thinking and research. International Journal of Operations \& Production Management, Vol. 32, Iss: 5: p. $551-582$.

Ohno, T. (1988): Toyota production system: beyond large-scale production. New York: Productivity Press

Shah, R. - Ward, P.T. (2007): Defining and developing measures of lean production. Journal of Operations Management, Vol. 25, No. 4: p. 785-805.

Spear, S. - Takeuchi, H. - Osono, E. - Norihiko Shimizu, N. (2008): The Contradictions That

Gelei A. - Losonci D. - Báthory Zs. - Toarniczky A. (2011): Leadership jellemvonások és lean menedzsment elmélet és gyakorlat. Projekt záró tanulmány. Bp.: BCE Vállalatgazdaságtan Intézet Versenyképesség Kutató Közp.

Holweg, M. (2007): The genealogy of lean production. Journal of Operations Manage-ment, 25: p. 420-437.

Jenei, I. - Renczes, N. - Losonci, D. (2012): Mit hozott nekünk a lean menedzsment? Minőség és Megbízhatóság, On-line

Kelemen T. (2009): A lean management magvalósításának jellegzetes problémái. Vezetéstudomány, XL. évfolyam, június különszám: 62-67. o.

Koenig, M. (2013): The Practical and Strategic Side of BPM. Aberdeen Group http://www.aberdeen.com/, Letöltve 2013. március 20.

Koltai T. - Romhányi G. - Tatay V. (2009): Optimalizálás bizonytalan paraméterekkel a termelés- és szolgáltatásmenedzsmentben. Vezetéstudomány, XL. évfolyam, június különszám: 68-73. o.
Drive Toyota's Success. Harvard Business Review, June: p. 96.

Tien, J. - Berg, D. (2003): A Case for Service Systems Engineering. Journal of Systems Science and Systems Engineering, 12(1): p. 13-38.

Womack, J.P. - Jones, D.T. - Roos, D. (1990): The Machine that Changed the World. New York: Rawson Associates Vörös J. (2010): Termelés- és szolgáltatásmenedzsment. Budapest: Akadémiai Kiadó

- http://calleam.com/WTPF/?page_id=1445 Letöltve 2013. március 4.

- http://www.aberdeen.com/_aberdeen/lean/-I/-//search.aspx, Letöltve 2012. június 26.

- http://www.emsstrategies.com/dm050104article2.html)

- RSM McGladrey Manufacturing and Whole sale Distributionnational online surveyconducted. Idézi http://www. usatoday.com/money/industries/manufacturing/2009-1101-lean-manufacturing-recession_N.htm, Letöltve 2012. szeptember 13. 